\title{
IMPLEMENTASI PEMBELAJARAN IPS TERHADAP PEMBENTUKAN KARAKTER SISWA DI SEKOLAH DASAR
}

\author{
Safinaz Sahira ${ }^{1^{*}}$, Rejeki $^{2}$, Miftahul jannah ${ }^{3}$, Rinda gustari $^{4}$, \\ Yuli asnita nasution ${ }^{5}$, Sulis windari ${ }^{6}$, Seri mulia reski ${ }^{7}$ \\ 1,2,3,4,5,6,7 STKIP Rokania, Pasir Pengaraian, Indonesia \\ Email:safinassahira796@gmail.com,
}

\begin{abstract}
Abstrak
IImu Pengetahuan Sosial (IPS) merupakan mata pelajaran yang memiliki peranan penting dalam membentuk warga negara yang baik, maka pembelajaran IImu Pengetahuan Sosial (Social Studies), sangatlah penting pada jenjang pendidikan dasar dimana pendidikan dasar merupakan keletakan dasar/pondasi pemahaman dan keilmuan tentang bagaimana hidup bersosial dalam masyarakat. Penelitian ini bertujuan untuk memperoleh Implementasi Pembelajaran IPS Terhadap Pembentukan Karakter Siswa Di Sekolah Dasar. Penelitian ini dilakukan di Kabupaten Rokan Hulu, yang bertempat di SD Negeri 010 Rambah pada tanggal 11 Desember 2021.dengan menggunakan metode penelitian deskriptif kualitatif. Sumber data yang diperoleh adalah data primer dan data sekunder dengan tekhnik pengumpulan datanya yaitu observasi, wawancara, dan dokumentasi. Subjek dalam penelitian ini adalah guru di Sekolah Dasar. Hasil penelitian ini dapat mengetahui karakter adalah suatu sifat individu, kepribadian seseorang, watak serta tingkah laku yang dimiliki seseorang dalam kehidupan seseorang. Karakter merupakan aspek utama dalam membentuk kualitas seseorang untuk dapat menjadi insan yang mulia. Pendidikan IPS berperan penting dalam menghasilkan peserta didik yang berkualitas, yaitu manusia yang mampu berfikir kritis, kreatif, logis, dan berinisiatif dalam menghadapi gejala dan masalah sosial yang berkembang di masyarakat.
\end{abstract}

Kata kunci: Pendidikan, Pembelajaran IPS, Pembentukan Karakter, Siswa

\begin{abstract}
Social Sciences (IPS) is a subject that has an important role in forming good citizens, so learning Social Sciences (Social Studies) is very important at the basic education level where basic education is the foundation of understanding and knowledge about how to live socialize in society. This study aims to obtain the implementation of social studies learning towards the formation of students' character in elementary schools. This research was conducted in Rokan Hulu Regency, which is located at SD Negeri 010 Rambah on December 11, 2021. Using qualitative descriptive research methods. Sources of data obtained are primary data and secondary data with data collection techniques namely observation, interviews, and documentation. The subjects in this study were teachers in elementary schools. The results of this study can determine the character is an individual trait, a person's personality, character and behavior that a person has in a person's life. Character is the main aspect in shaping a person's quality to be a noble person. Social studies education plays an important role in producing quality students, namely humans who are able to think critically, creatively, logically, and take the initiative in dealing with social symptoms and problems that develop in society.
\end{abstract}

Keywords: Education, Social Studies Learning, Character Building, Students 


\section{Pendahuluan}

Pendidikan merupakan salah satu hal terpenting dalam kehidupan seseorang. Pendidikan lah yang menentukan dan menuntun masa depan dan arah hidup seseorang. Walaupun tidak semua orang berpendapat seperti itu, namun pendidikan tetap lah menjadi kebutuhan manusia nomor wahid(Mahmud, 2017). Bakat dan keahlian seseorang akan terbentuk dan terasah melalui pendidikan. Pendidikan juga umumnya dijadikan untuk mengukur kualitas setiap orang. Dalam bahasa latin pendidikan berarti educatum yang berasal dari kata "E" dan "Duco", "E" berarti perkembangan dari luar atau perkembangan dari sedikit menuju banyak, sedangkan "Duco" berarti sedang berkembang(Istiq'faroh, 2020). Dari sini, pendidikan bisa juga disebut sebagai upaya guna mengembangkan kemampuan diri(Mursyidi, 2020).

Menurut Wikipedia, pendidikan adalah pembelajaran pengetahuan, keterampilan, serta kebiasaan sekelompok orang yang diturunkan dari satu generasi ke generasi selanjutnya melalui pengajaran. Sedangkan, Menurut Kamus Besar Bahasa Indonesia (KBBI), pendidikan adalah proses pengubahan sikap dan tata laku seseorang atau sekelompok orang dalam upaya mendewasakan manusia melalui sebuah pengajaran maupun pelatihan(Sudaryanto, 2020). Menurut Ki Hajar Dewantara ia mengemukakan bahwa pengertian pendidikan adalah tuntutan tumbuh dan berkembangnya anak(Sugiarta et al., 2019). Artinya, pendidikan merupakan upaya untuk menuntun kekuatan kodrat pada diri setiap anak agar mereka mampu tumbuh dan berkembang sebagai manusia maupun sebagai anggota masyarakat yang bisa mencapai keselamatan dan kebahagiaan dalam hidup mereka.

Tujuan Pendidikan Nasional yang tercantum dalam UU No.20 Tahun 2003 menyatakan bahwa tujuan pendidikan adalah mewujudkan suasana belajar dan proses pembelajaran agar peserta didik secara aktif dapat mengembangkan potensi dirinya untuk memiliki kekuatan spiritual keagamaan, pengendalian diri, kepribadian, kecerdasan, akhlak mulia, serta keterampilan yang diperlukan dirinya, masyarakat, bangsa dan negara(UU Sisdiknas, 2003). Sehubungan dengan tujuan pendidikan tersebut, pemerintah berupaya untuk meningkatkan kualitas pendidikan agar dapat menghasilkan sumber daya manusia yang cerdas, berkualitas, berkarakter dan berbudaya. Peningkatan kualitas sumber daya manusia dapat ditempuh melalui perbaikan sistem pendidikan yang mengarah pada pembentukan karakter siswa sejak tingkat pra-sekolah sampai perguruan tinggi. Pembentukan karakter sebagai upaya meningkatkan perilaku siswa dilaksanakan secara berkesinambungan yang melibatkan aspek knowledge, feeling, dan acting (Soetari, 2014).Ilmu Pengetahuan Sosial (IPS) merupakan mata pelajaran yang memiliki peranan penting dalam membentuk warga negara yang baik, maka pembelajaran ilmu pengetahuan sosial (social studies), sangatlah penting pada jenjang pendidikan dasar dimana pendidikan dasar merupakan keletakan dasar/ fondasi pemahaman dan keilmuan tentang bagaimana hidup bersosial karena disekolah siswa yang datang dari lingkungan yang berbeda-beda, sisi lain dari itu juga bahwa kepedulian terhadap lingkungan sosial atau memiliki pengetahuan dan pemahaman tentang sosial itu dari pada nilai-nilai pendidikan karakter bangsa. Seperti yang dijelaskan diatas, tentu pengenalan dan penguatan ilmu pengetahuan sosial terus dikembangkan sedalam mungkin untuk membentuk karakter siswa sekolah. Ada tiga tujuan pembelajaran IPS kepada siswa, yaitu agar setiap siswa menjadi warga masyarakat yang baik, melatih siswa berkemampuan berpikit matang 
untuk menghadapi dan memecahkan masalah-masalah sosial, dan agar siswa dapat mewarisi dan melanjutkan budaya dan cita-cita bangsa indonesia.

National Council for Social Studies (NSCC) mendefinisikan IImu Pengetahuan Sosial sebagai berikut :

"Social studies as "the integrated study of the social science and humanities to promote civic competence ". Within the school program, social studies provides coordinated, systematic, study drawing upon such disciplines as anthropology, archeology, ecenomics, geography, law, philosophy religion and sociology, as well as appropriate content from the humanities, mathematic and natural sciences. (D., 1922; NCSS, 2009)"

Melalui pembelajaran IImu Pengetahuan Sosial, siswa diajarkan untuk menjadi warga Negara Indonesia yang baik dan penuh kedamaian. IImu Pengetahuan Sosial diperlukan bagi keberhasilan transisi kehidupan menuju pada kehidupan yang lebih dewasa dalam upaya membentuk karakter bangsa yang sesuai dengan prinsip dan semangat nasional. Dengan demikian para siswa dalam pembelajaran IPS terlatih untuk menyelesaikan persoalan sosial dengan pendekatan secara holistik dan terpadu dari berbagai sudut pandang.

Proses pembelajaran karakter dalam pembelajaran IPS lebih diarahkan pada aspek pengetahuan, keterampilan dan perilaku, terdapat tiga aspek dalam pembelajaran yang harus dicapai yaitu ; "a) knowledge, which is a body of fact and principles; b) skill, which is acquiring an ability through experience or training; $c$ ) attitude, which is one openion, feeling or mental set as demonstrated by one action"(Mursyidi, 2020). Pendidikan karakter merupakan proses untuk membentuk, menumbuhkan, mengembangkan dan mendewasakan kepribadian anak menjadi pribadi yang bijaksana dan bertanggung jawab melalui pembiasaan pikiran, hati dan tindakan secara berkesinambungan yang hasilnya dapat terlihat dalam proses pembelajaran serta tindakan nyata sehari-hari baik di sekolah maupun di masyarakat. Pembelajaran IPS memiliki peranan penting dalam pembentukan karakter siswa. Didalam penelitiannya Ali Ibrahim Akbar (Marhayani, 2018)) menjelaskan bahwa kesuksesan seseorang hanya ditentukan $20 \%$ oleh hard skill dan sisanya $80 \%$ oleh soff skill. Dari penjelasan tersebut menunjukkan bahwa sangat penting sekali dalam melakukan pembentukan karakter terhadap siswa. Siswa yang memiliki kekuatan mental dan memiliki akhlak yang baik tentunya akan dapat emilki kepribadian yang berkarakter. Hal tersebut dapat membedakannya dengan siswa yang lain. Pembelajaran IPS dalam pembentukan karakter siswa tentunya bukanlah hal yang mudah, perlu perjuangan yang berkesinambungan agar menghasilkan hasil yang sesuai dengan tujuan pendidikan nasional.

(Anis et al., 2020) mengatakan pembelajaran IPS selalu mendapat sorotan terkait dengan peran guru dan kondisi siswa. Guru masih memegang kendali utama pembelajaran, sedang siswa hanya mengikuti arahan guru. Ironisnya siswa hanya disuguhkan metode hapal-hapalan terhadap pembelajaran sehingga mengakibatkan siswa mengalami kejenuhan saat belajar. Proses pembelajaran yang dilakukan tersebut menunjukkan bahwa betapa pembelajarn ips masih belum dapat menumbuhkan dan meningkatkan karakter diri siswa secara maksimal, khususnya dalam hal penanaman nilanilai karakter dalam kehidupan sehari-hari yang dialami siswa.

Fenomena yang terjadi pada saat ini menunjukkan adanya gejala kemerosotan yang sangat mengkhawatirkan. Kebenaran, kejujuran, keadilan, tolongmenolong dan kasih sayang sudah mulai menjadi barang mahal dan tertutup oleh penyelewengan, penipuan, penindasan, 
saling acuh tak acuh, mengambil hak orang lain, dan masih banyak lagi tindakan-tindakan menyimpang lainnya. Dunia pendidikan di Indonesia kini sedang memasuki masa-masa pelik. Kucuran anggaran pendidikan yang besar disertai berbagai program terobosan sepertinya belum mampu memecahkan persoalan mendasar dalam dunia pendidikan, yakni bagaimana mencetak alumni pendidikan yang unggul, yang beriman, bertakwa, profesional, dan berkarakter. Oleh karena itu seperti negara berkembang lainnya, Indonesia sedang berusaha membangun karakter anak bangsa untuk memperbaiki citra bangsa sampil tetap mempertahankan identitas kulturalnya.

Pendidikan karakter dimaksudkan sekaligus sebagai pembentukan karakter. Pendidikan karakter itu sendiri merupakan sebuah proses yang panjang, yaitu proses pembelajaran untuk menanamkan nilai-nilai luhur, budi pekerti, akhlak mulia yang berakar pada ajaran agama, adat-istiadat, dan nilai-nilai keindonesiaan dalam rangka mengembangkan kepribadian peserta didik supaya menjadi manusia yang bermartabat, menjadi warga bangsa yang berkarakter sesuai dengan nilai-nilai luhur bangsa dan agama. Dengan demikian, siswa membutuhkan pendidikan karakter yang kakan membentuk karakter yang positif. Pemerintah melalui Kementerian Pendidikan dan Kebudayaan sudah mencanangkan pendidikan karakter untuk semua tingkat pendidikan, dari SD sampai pada tingkat Perguruan Tinggi. Pembentukan karakter perlu dilakukan sejak usia dini. Munculnya gagasan program pendidikan karakter dalam dunia pendidikan di Indonesia, bisa dimaklumi, sebab selama ini dirasakan, proses pendidikan ternyata belum berhasil membangun manusia Indonesia yang berkarakter

\section{Metode Penelitian}

Penelitian ini dilakukan di Kabupaten Rokan Hulu, yang bertempat di SD Negeri 010 Rambah pada tanggal 11 Desember 2021. Sumber data yang digunakan yaitu data primer dan data sekunder. Data primer adalah data yang diperoleh secara langsung melalui wawancara terhadap para informan, sedangkan data sekunder adalah dokumen-dokumen yang bisa dipublikasikan. Adapun tekhnik pengumpulan data yaitu observasi, wawancara, dan dokumentasi.Adapun metode dalam penelitian ini adalah dengan menggunakan pendekatan kualitatif sehingga data yang dihasilkan berupa kata-kata yang bersifat deskriptif yaitu dengan menganalisis mengenai Implementasi Pembelajaran IPS Terhadap Pembentukan Karakter Siswa Di Sekolah Dasar. sifat penelitian kualitatif deskriptif berarti penelitian kualitatif yang selalu menyajikan temuannya dalam bentuk deskripsi kalimat yang rinci, lengkap, dan mendalam mengenai proses mengapa dan bagaimana sesuatu terjadi(Gunawan, 2013; Moleong, 2018; Nugrahani \& Hum, 2014). Dengan menggunakan penelitian kualitatif deskriptif, peneliti akan mampu menangkap berbagi informasi kualitatif dengan deskripsi teliti. Data yang diperoleh kemudian dianalisis menjadi suatu kesimpulan menjadi proses penelitian.

\section{Hasil dan Pembahasan}

Pada penelitian ini memaparkan dan menyajikan gambaran umum mengenai Implementasi Pembelajaran IPS Terhadap Pembentukan Karakter Siswa Di Sekolah Dasar. Berdasarkan wawancara dan observasi yang telah dilakukan pada Sabtu 11 Desember 2021 diperoleh berbagai data terkait Pembelajaran IPS dan Pembentukan Karakter Siswa.Adapun hasil wawancara tersebut adalah perihal karakter "Karakter 
adalah suatu sifat individu, kepribadian seseorang, watak serta tingkah laku kehidupan sehari-hari". (Ermianti, S.Pd wali kelas $V$ )."Karakter adalah sifat, watak, serta tingkah laku yang dimiliki seseorang dalam kehidupan sehari-hari". (Saipul, S.Pd guru kelas V ). Untuk membentuk karakter siswa maka guru

Mengajarkan siswa dengan sopan santun, serta bersikap jujur atau terbuka dalam kesalahannya dan berbagi pengalaman inspiratif dan cerita yang positif. "Memberikan apresiasi atau penghargaan sekecil ataupun kepada siswa. Hal ini akan membuat siswa lebih merasa percaya diri dan semakin bersemangat dalam belajar. menyikapi karakter yang berbeda-beda yang ada pada anak Sekolah Dasar Seorang guru harus tegas kepada muridnya, walaupun kita belajar dengan lemah lembut tidak sepenuhnya karena setiap siswa mempunyai karakter yang berbeda-beda. Memberikan motivasi kepada siswa saat mengakhiri pelajaran, dan menggunakan metode pembelajaran yang menarik untuk belajar. Tidak membeda-bedakan antara siswa yang satu dengan siswa yang lainnya, bersikap adil, serta menerapkan model pembelajaran yang tepat.perihal angket pembelajaran IPS dapat membentuk karakter anak pasti sangat penting karena pendidikan karakter dalam pembelajaran IPS di Sekolah Dasar, peserta didik yang berkarakter positif, beretika, bermoral, berakhlak dan bertingkah laku yang baik. Pendidikan karakter seharusnya dimulai sidini dari kecil sudah diajarkan oleh orang tua. siswa diajarkan bersikap sopan santun, serta bagaimana caranya berbaur dengan masyarakat. Tentang peran pembelajaran IPS di Sekolah Dasar Menggunakan pemanfaatan media pembelajaran yang menarik menggunakan metode kooperatif. Contoh seorang guru memberikan tugas dan kerjakan bersama teman sekelompok dengan menyelesaikan masalah yang diketahui ditugas tersebut. Jika seorang siswa tidak paham maka guru harus menjelaskan bagaimana mengerjakannya dengan bantuan media pembelajaran Penerapan Pembelajaran IPS di Sekolah Dasar bisa diterapkan dengan menggunakan model pembelajaran yang sesuai dengan karakter siswa. Perihal angket peran pelajaran IPS dalam pembentukan karakter siswa di Sekolah Dasar Pendidikan IPS sebenarnya sangat erat kaitannya dengan pendidikan karakter. Mengembangkan pengetahuan dan pemahaman siswa terhadap sosial dalam bermasyarakat didaerahnya.Peran Pembelajaran IPS sangat penting dalam pembentukan karakter siswa, karena dalam Pembelajaran IPS selain untuk mengembangkan pengetahuan kita juga diajarkan bagaimana caranya bersosialisasi dengan masyarakat. dalam pendidikan IPS harus diintegrasikan dengan pendidikan karakter Integrasi yang dimaksud adalah bagaimana pendidikan karakter itu tergabung kedalam pembelajaran sehingga mengajarkannya itu tidak terpisah, tetapi menjadi satu kesatuan.Karena Pendidikan IPS dan karakter siswa itu sering berhubungan. Pendidikan IPS mempelajari tentang kehidupan masyarakat dan pendidikan karakter berhubungan dengan tingkah laku anak dalam kehidupan sehari-hari.

Dari hasil wawancara yang dilakukan kepada guru kita dapat mengetahui karakter adalah suatu sifat individu, kepribadian seseorang, watak serta tingkah laku yang dimiliki seseorang dalam kehidupan seseorang. Karakter merupakan aspek utama dalam membentuk kualitas seseorang untuk dapat menjadi insan yang mulia. Apabila kualitas diri seseorang baik dan senantiasa ditumbuh kembangkan, maka seseorang tersebut dapat menjadi manusia yang bermanfaat bagi lingkungan sekitar dan kemajuan bangsa. Dengan begitu dapat diartikan pendidikan karakter harus diupayakan oleh satuan 
pendidikan, untuk meningkatkan mutu penyelenggaraan dan hasil pendidikan di sekolah yang mengarah pada pencapaian pembentukan karakter siswa. Penanaman pendidikan karakter penting dilaksanakan di sekolah, agar mengarahkan dan menguatkan siswa untuk berkarakter. Pentingnya pendidikan karakter diamanatkan sebagaimana tertulis dalam UU No.20 Tahun 2003 tentang Sistem Pendidikan Nasional pasal 3 menyatakan bahwa : Pendidikan Nasional berfungsi mengembangkan kemampuan dan membentuk watak serta peradaban bangsa yang bermartabat dalam rangka mencerdaskan kehidupan bangsa, bertujuan untuk berkembangnya potensi siswa agar menjadi manusia yang beriman dan bertakwa kepada Tuhan Yang Maha Esa, berakhlak mulia, sehat, berilmu, cakap, kreatif, mandiri, dan menjadi warga negara yang demokratis serta bertanggung jawab.

Pentingnya karakter menjadi persoalan yang sangat serius dibahas. Pemerintah telah mengisipkan pendidikan karakter dalam kurikulum (2013). Pendidikan karakter dalam kurikulum 2013 dimasukan dalam kompetensi inti bagian 1 dan 2 . Kompetensi yang berkenaan dengan sikap keagamaan dan sosial dikembangkan secara tidak langsung (inderecete teaching) yaitu pada waktu peserta didik belajar tentang pengetahuan (kompetensi inti 3) dan perencanaan pengetahuan (kompetensi 4). Sesuai dengan rancangan kurikulum 2013 yakni memusatkan perhatian besar pada karakter di sekolah besar sebelum anak memasuki jenjang pendidikan SMP dan seterusnya. Nilai-nilai karakter yang dikembangkan dalam Kemendiknas ada delapan belas karakter antara lain: karakter religius, jujur, disiplin, toleransi, kerja keras, kreatif, mandiri, demokratis, rasa ingin tahu, semangat kebangsaan, cinta tanah air, menghargai prestasi, bersahabat, cinta damai, gemar membaca, peduli lingkungan, peduli sosial, dan bertanggung jawab. Pada jenjang sekolah dasar khususnya kelas rendah diharapkan siswa memiliki lima karakter dasar, yaitu : religius, jujur, disiplin, mandiri, dan tangung jawab. Tuntunan, hal yang paling sederhana yang bisa dilakukan adalah dengan cara mejadi contoh/figur/teladan yang baik bagi peserta didik. Pendidikan karakter bukan sekedar deretan ilmu, pengetahuan namun aksi positif dari pengetahuan yang sudah didapat.

Karakter tidak terbentuk begitu saja, tetapi terbentuk melalui beberapa faktor yang mempengaruhi, yaitu: faktor biologis dan faktor lingkungan.Faktor Biologis Faktor Biologis yaitu faktor yang berasal dari dalam diri orang itu sendiri. Faktor ini berasal dari keturunan atau bawaan yang dibawa sejak lahir dan pengaruh keturanan dari salah satu sifat yang dimilki salah satu dari keduanya.Faktor Lingkungan Disamping faktor-faktor Hereditas (faktor endogin) yang relatif konstan, sifatnya, yang terdiri antara lain atas lingkungan hidup, pendidikan, kondisi dan situasi hidup dan kondisi masyarakat (semuanya merupakan faktor eksogin) semuanya berpengaruh besar terhadap pembentukan karakter.

Pengembangan karakter siswa melalui buku saja belum cukup karena diperlukan keterampilan guru dalam membangkitkan demokratis, kreatifitas, dan kemandirian siswa. Sebagai contoh guru perlu melatih siswa untuk berkomunikasi. Menurut James A. F. Stoner komunikasi adalah suatu proses pada seseorang yang berusaha untuk memberikan pengertian dan informasi dengan cara menyampaikan pesan kepada orang lain. Respon guru sangat penting dalam membentuk tingkah laku siswa. Respon yang bersifat kritik yang merendahkan atau menjatuhkan siswa merupakan suatu hal yang harus dihindari. Pemberian pujian merupakan suatu pemberian respon yang efektif, tetapi perlu diperhatian pemberian perhatian tersebut haruslah sungguh- 
sungguh berarti bagi siswa. Pemberian pujian yang berlebihan dan tidak pada tempatnya akan membuat pujian itu tidak bermakna bagi siswa. Pujian yang diberikan secara tepat akan membuat siswa termotivasi untuk melakukan yang terbaik.

Dalam satu kelas, kita pasti akan menemukan keberagaman. Lalu bagaimana sebaiknya sikap guru menghadapi keberagaman karakter siswa yang berbeda-beda. Cara yang harus dilakukan oleh seorang guru dalam menyikapi karakter siswa yang berbedabeda yaitu dengan cara: Memilih metode pembelajaran yang tepat.Metode pembelajaran yang hanya membaca saja mungkin tidak cocok untuk anak yang mengandalkan kemampuan audio. Sebaliknya, tidak semua anak bisa menangkap materi hanya dengan penjelasan. Dengan mengetahui karakter apa saja yang ada dikelas, kita bisa memadukan beragam metode pembelajaran untuk satu materi agar bisa dipahami oleh semua anak.Memperlakukan peserta didik secara adil.Tidak semua anak memiliki kemampuan yang sama dalam satu mata pelajaran. Salah satu sikap guru dalam menghadapi perbedaan karakter ini adalah tetap memperlakukan semua siswa dengan sama rata. Terlepas dari beberapa besar kemampuan mereka dalam menerima materi yang diajarkan.

Memberikan motivasi yang tepat. Kita mungkin akan menemukan siswa yang tidak mempunyai kemamouan berbahasa sehebat teman-temannya yang lain. Disinilah peran kita sebagi seorang guru untuk memberikan motivasi yang tepat. Alih-alih menganggap kemampuannya yang minim sebagai kekurangan, coba temukan kelebihannya yang lain. Setelah itu dorong anak untuk mengembangkan potensi yang ia miliki. Dengan begitu, anak tidak merasa kurang berharga dibanding teman-temannya yang lain.
Pelajaran IPS di sekolah dasar dapat membentuk karakter anak karena dalam pembelajaran IPS di sekolah dasar, siswa diajarkan bersikap sopan santun, beretika, bermoral, berakhlak, bertingkah laku yang baik serta bagaimana caranya berbaur dengan masyarakat. Dalam kegiatan pembelajaran IPS merupakan salah satu mata pelajaran yang strategis untuk menanamkan nilai-nilai moral kepada peserta didik. Kirschenbaum menegaskan, bahwa tujuan akhir dari studi Ilmu Pengetahuan Sosial adalah diarahkan untuk tujuan pendidikan moral. Pendidikan IPS sebagai bagian dari pendidikan secara umum memiliki peran penting dalam meningkatkan mutu pendidikan. Secara khusus pendidikan IPS turut serta berperan dalam menghasilkan peserta didik yang berkualitas, yaitu manusia yang mampu berfikir kritis, kreatif, logis, dan berinisiatif dalam menghadapi gejala dan masalah sosial yang berkembang di masyarakat yang diakibatkan oleh perkembangan teknologi di Era global.

Mempelajari IPS pada dasarnya adalah mengembangkan pengetahuan, nilai, sikap, serta keterampilan sosial siswa untuk dapat menelaah kehidupan sosial yang dihadapi sehari-hari dengan tujuan agar siswa mampu mengembangkan pengetahuan, nilai, dan sikap, serta keterampilan sosial yang berguna bagi dirinya. Dengan demikian, pendidikan IPS tidak dapat menghindari tugas pengembangan moral dan etika. Dalam pembelajaran IPS, salah satu hal yang penting untuk diperhatikan adalah metode pembelajaran. Selama ini metode pembelajaran IPS yang berkembang di sekolah adalah metode fungsional. Adapun kriteria dari metode fungsional tersebut, yaitu: (1) memiliki standar objektivitas yang kaku, (2) mengaju pada pengembangan kognitif, dan (3) guru juga lebih banyak mengejar target yang berorientasi pada nilai ujian akhir sehingga berakibat siswa lebih suka 
menghapal materi dari pada memahami esensi dari ilmu yang disampaikan guru di kelas.

\section{Kesimpulan}

Berdasarkan hasul penelitian kualitatif dengan teknik pengumpulan datanya yaitu wawancara dan dokumentasi yang dilakukan di kelas $\mathrm{V}$ SDN 010 Rambah tahun ajaran 20202021 tentang implementasi pembelajaran IPS terhadap pembentukan karakter siswa di sekolah dasar dapat diambil beberap kesimpulan. Karakter adalah suatu sifat individu, kepribadian seseorang, watak serta tingkah laku yang dimiliki seseorang dalam kehidupan sehari-hari. Karakter merupakan aspek utama dalam membentuk kualitas seseorang agar dapat menjadi insan yang mulia. Apabila kualitas diri seseorang baik dan senantiasa ditumbuh kembangkan, maka seseorang tersebut dapat mendapat manusia yang bermanfaat bagi lingkungan sekitar dan kemajuan bangsa.

Pelajaran IPS di sekolah dasar dapat membentuk karakter anak karena dalam pembelajaran IPS siswa diajarkan bersifat sopan santun, beretika, bermoral, berakhlak, bertingkah laku yang baik serta bagaimana caranya berbaur dengan masyarakat. Pembelajaran IPS merupakan salah satu mata pelajaran yang strategis untuk menanamkan nilainilai moral kepada peserta didik. John Dewey mengemukakan bahwa proses dan tujuan akhir studi-studi sosial harus bermuara pada terwujudnya moral dalam mengembangkan kepribadian manusia (Sjarkw, 2008). Pendidikan IPS berperan penting dalam menghasilkan peserta didik yang berkualitas, yaitu manusia yang mampu berfikir kritis, kreatif, logis, dan berinisiatif dalam menghadapi gejala dan masalah sosial yang berkembang di masyarakat.

\section{Daftar Pustaka}

Anis, M. Z. A., Putro, H. P. N., Susanto, H., \& Hastuti, K. P. (2020). Historical Thinking Model in Achieving Cognitive Dimension of Indonesian History Learning. PalArch's Journal of Archaeology of Egypt/Egyptology, 17(7), 7894-7906.

D., E. (1922). National Council for the Social Studies. The American Historical Review, 27(3). https://doi.org/10.2307/1837803

Gunawan, I. (2013). Metode penelitian kualitatif. Jakarta: Bumi Aksara, 143.

Istiq'faroh, N. (2020). Arti Pendidikan. Lintang Songo : Jurnal Pendidikan, 3(2).

Mahmud. (2017). Psikologi Pendidikan. Bandung: Pustaka Setia.

Marhayani, D. A. (2018). Pembentukan karakter melalui pembelajaran IPS. Edunomic: Jurnal IImiah Pendidikan Ekonomi Fakultas Keguruan Dan IImu Pendidikan, 5(2), $67-75$.

Moleong, L. J. (2018). Metodologi Penelitian Kualitatif, cet. In XI. Bandung: PT Remaja Rosdakarya.

Mursyidi, W. (2020). Kajian Teori Belajar Behaviorisme Dan Desain Instruksional. Almarhalah / Jurnal Pendidikan Islam, 3(1). https://doi.org/10.38153/alm.v3i1.30

NCSS. (2009). Media literacy: A position statement of National Council for the Social Studies. Social Education, 73(4). 
Safinaz Sahira, Rejeki, dkk.

Nugrahani, F., \& Hum, M. (2014). Metode penelitian kualitatif. Solo: Cakra Books.

Soetari, E. (2014). Pendidikan Karakter dengan Pendidikan Anak untuk Membina Akhlak Islami. Pendidikan Universitas Garut, 08(01).

Sudaryanto, S. (2020). Kamus Besar Bahasa Indonesia Edisi Kelima Dalam Pembelajaran Bahasa Indonesia (Perspektif Filsafat Pendidikan Bahasa). Lateralisasi, 08.

Sugiarta, I. M., Mardana, I. B. P., Adiarta, A., \& Artanayasa, W. (2019). FILSAFAT PENDIDIKAN KI HAJAR DEWANTARA (TOKOH TIMUR). Jurnal Filsafat Indonesia, 2(3). https://doi.org/10.23887/jfi.v2i3.22187

UU Sisdiknas, N. 20. (2003). Undang-Undang Sistem Pendidikan Nasional. Records Management Journal, 1(2). 